\title{
Reports
}

\section{The COVID-19 global pandemic: a review of the Vietnamese Government response}

\author{
Luong T T Tran', Edit O Manuama ${ }^{2}$, Duc P Vo ${ }^{3}$, Huy V Nguyen ${ }^{4}$, Raisa Cassim ${ }^{5}$, Minh Pham ${ }^{6}$, Dinh S Bui ${ }^{5}$ \\ 1 Independent Researcher, Ha Noi, Vietnam, ${ }^{2}$ Independent Researcher, Jakarta, Indonesia, ${ }^{3}$ University of Science and Technology, the University of \\ Danang, Vietnam, ${ }^{4}$ Health Innovation and Transformation Centre, Federation University, Mt Helen, Ballarat, Victoria, Australia; Graduate School of \\ Public Health, St. Luke's International University, Tokyo, Japan, 5 Center for Epidemiology and Biostatistics, School of Population and Global Health, \\ The University of Melbourne, Australia, ${ }^{6}$ Burnet Institute, Melbourne Australia; School of Public Health and Preventive Medicine, Monash University, \\ Australia
}

Keywords: covid-19 control, public health measure, vietnam, health policy, covid-19

https://doi.org/10.29392/001c.21951

\section{Journal of Global Health Reports}

Vol. 5, 2021

\begin{abstract}
The profound effect of COVID-19 pandemic has not eluded Vietnam, a lower-middle-income country that borders China, the country where the outbreak originated. Currently facing a second wave, Vietnam experienced several months of insignificant community-transmission, when the epidemic was effectively under control. This paper provides an account of the policies developed by the national COVID-19 response team during the first wave, from January to July 2020. Three key components were identified, including (i) the timely and decisive responses from the national and local authorities in the early phase of the pandemic, (ii) a society-wide approach, supported by an effective risk communication strategy which managed to gain the public trust, and (iii) an effective preventive medicine and infectious disease control system, residing in early case identification, strict isolation, effective contact tracing and compulsory quarantine of close contacts. While several other important components of the health system, such as financing and human resources remain largely under-explored, the results of this study show that a mixture of measures may lead to an effective epidemic management.
\end{abstract}

In early December 2019, pneumonia with an unknown etiology was reported among a cluster of patients in a hospital in Wuhan, Hubei Province, China. ${ }^{1}$ One month later, the World Health Organization (WHO) declared COVID-19, the disease caused by a novel coronavirus (SARS-CoV-2), a Public Health Emergency of International Concern. ${ }^{2}$ After realization of the rapidly increasing number of confirmed cases and the growing number of affected countries, COVID-19 was declared a global pandemic on $11^{\text {th }}$ March $2020 .^{3}$ By $19^{\text {th }}$ July, there were more than 14 million confirmed cases and near 600 thousand deaths reported globally. ${ }^{4}$ The United Stated of America and Europe were most affected, reporting around 7.3 million deaths and more than 3 million cases which accounted for nearly three quarters of the total cases globally. 4

Vietnam was among the first countries to be affected by the virus, however, the country responded promptly in order to gain early control of the COVID-19 epidemic. The first two cases reported in the country were two Chinese men who had traveled from Wuhan on $23^{\text {rd }}$ January. ${ }^{5,6}$ Subsequently, the number of confirmed cases in Vietnam increased steadily, and by $30^{\text {th }}$ June, the nation had recorded 355 cases without a single lethal outcome; 325 patients recovered completely and were discharged from hospitals. ${ }^{7}$ As a final result, Vietnam, a low-income country, has been internationally recognized for its effective control measures which resulted in zero deaths and 99 uninterrupted days without a single community case by $19^{\text {th }}$ July. ${ }^{7}$

Currently, information about the COVID-19 outbreak and control measures in Vietnam is available in various governmental websites, local newspapers and experts' analyses. To the best of our knowledge, a limited number of academic papers discussed the spread and management of COVID-19 in Vietnam. Of these articles, some published reviews highlighted that an early response, governmental preparedness, strong political figures, the operational readiness of grassroots health system and roles of social media all contributed substantially to the successful control of COVID-19 in Vietnam. ${ }^{8-11}$ However, there has been little discussion of the details of these policies and how they have been implemented systematically. This is important as it may provide some insight for other countries. ${ }^{8-11}$

How society-wide approach and systemic response is achieved in a centralized government like Vietnam remains unclear. Some studies overlook the importance of the Vietnamese health system's infection prevention and control measures when discussing control of the outbreak. Of further importance is an understanding of how a lower-middle-income country with limited resources such as Vietnam was able to effectively manage the outbreak that cost thousands of lives in many developed countries.

This paper aims to overview the key Vietnamese stateled responses for controlling the COVID-19 pandemic in the context of social structure, politics and the public health 
system. This analysis will inform the general public, public health experts and policymakers about contextualized responses to a global health crisis and discuss valuable lessons learned for future reference. Specifically, this study uses the WHO's strategic response plan that was released on $14^{\text {th }}$ April as a framework to analyze Vietnam's responses and policies during the first wave of the pandemic (up to $19^{\text {th }}$ July). ${ }^{12}$

This paper begins with a review on the context of the COVID-19 outbreak in Vietnam, followed by the analysis of the governmental response, and finally concludes with a discussion of how the responses contributed to containing the spread of the disease both domestically and globally.

\section{METHODS}

This paper is a narrative review of Vietnam's policy response to COVID-19. We reviewed the governmental documents and technical guidelines issued by the state government and the Ministry of Health $(\mathrm{MoH})$, a national body responsible for the management and coordination of COVID-19 related activities . Documents including a timeline of the spread of COVID-19 within Vietnam were digitally collected. The inclusion criteria for this review were COVID-19 policy response letters or technical guidelines issued by the Prime Minister, the Ministry of Health and other ministries where relevant between December 2019 to $19^{\text {th }}$ July.

Official COVID-19 response documents issued by local governments, academic articles, official reports from technical agencies and official newspapers' articles were used to provide insight into the country's outbreak, and to illustrate how policies were implemented. Vietnam's COVID-19 statistics provided in this paper were collected from the website of the General Department of Preventative Medicine, the Ministry of Health (https://ncov.vncdc.gov.vn/).

This paper excludes articles from non-official websites and social media posts. Additionally, we did not provide a detailed discussion of policy implementation or economic COVID-19 relief packages.

This paper uses the WHO's updated strategic response plan, released on $14^{\text {th }}$ April, as a framework from which to analyze responses and policies. The framework comprises of five sections: (1) coordination and planning, (2) engagement and mobilization of communities to limit exposure, (3) implementation of context-appropriate public health measures, (4) provision of clinical care and maintenance of essential health services to reduce mortality and (5) adapting strategies based on risk, capacity and vulnerability. The Vietnamese government's COVID-19 response policies were first selected and then analyzed. As this study was a review of publicly available reports and studies, no additional ethical approval was sought.

\section{RESULTS}

\section{AN OVERVIEW OF THE COVID-19 SITUATION IN VIETNAM}

Vietnam has a GDP of approximately USD 2,700 per capita. Total health expenditure was estimated at approximately

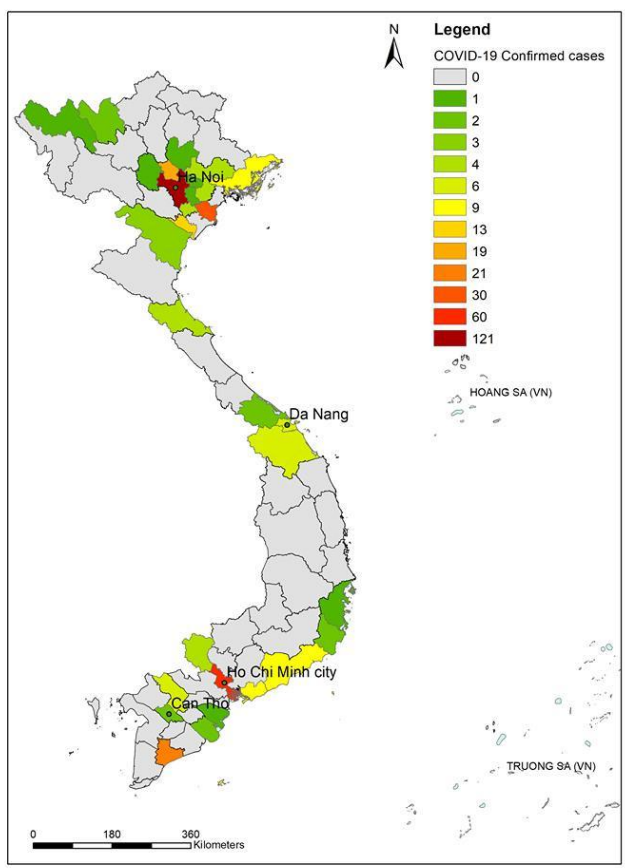

Figure 1. Summary of COVID-19 confirmed cases across Vietnam by $30^{\text {th }}$ June 2020 .

Figures were generated from the General Department of Preventative Medicine (https://ncov.vncdc.gov.vn/). Accessed: 10 July 2020.

6.6\% of the total GDPand up to $31.3 \%$ of health care costs are out-of-pocket. ${ }^{13-15}$ Vietnam is one of the five countries including Japan, the Republic of Korea, Thailand and the United States of America (USA) where COVID-19 cases were first confirmed outside of China; however, Vietnam was fast to implement impressive and effective control measures against COVID-19.16 The first two cases in Vietnam were identified on $23^{\text {rd }}$ January. By the end of the first wave of the pandemic (19 $9^{\text {th }}$ July), Vietnam declared that $70.1 \%$ of cases were imported and there had been no fatalities. ${ }^{7} \mathrm{~A}$ summary of the distribution of COVID-19 cases across the country by $30^{\text {th }}$ June is presented in Figure 1 . The majority of cases were concentrated in the two largest cities - Ha Noi and Ho Chi Minh. The first wave of the pandemic can be temporarily divided into three sub-stages: epidemiological linkage, the government responses and the presence of community transmission cases (Figure 2).

The first stage of the first wave began when the first case was declared and lasted until $6^{\text {th }}$ March. This stage reflects patients who were epidemiologically linked to Wuhan, China (16/16 cases), of which $50 \%$ were imported cases. ${ }^{7}$ On $1^{\text {st }}$ February, the Prime Minister announced the outbreak following the first recorded occurrence of local transmission in Vietnam. The country immediately deployed tight measures against the pandemic including travel restrictions and bans, visa suspensions, compulsory quarantine and health declarations for heavily affected countries (China, Republic of Korea, Iran and Italy), as well as a nationwide school shutdown. ${ }^{17-19}$ From $14^{\text {th }}$ February to $6^{\text {th }}$ March, there were no recorded cases. ${ }^{7}$ Consequently, the government began to stimulate international tourism from countries less affected by COVID-19, and Vietnamese citizens living 


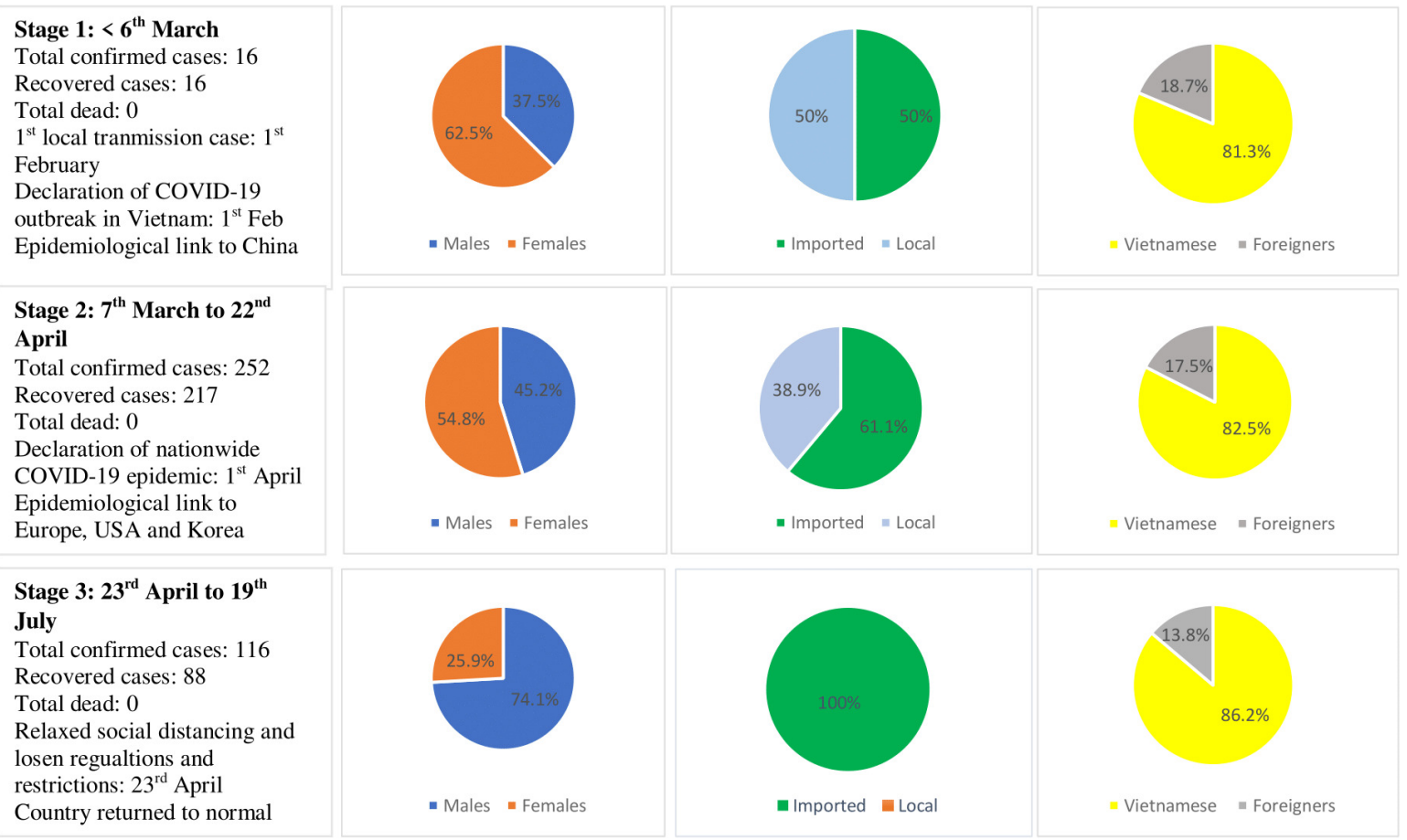

Figure 2. An overview of COVID-19 situation in Vietnam by $19^{\text {th }}$ July 2020.

Figures were generated from the General Department of Preventative Medicine (https://ncov.vncdc.gov.vn/). Accessed:: 30 July 2020

abroad were repatriated. However, a lapse in COVID-19 control caused by poor screening of potentially ill travelers from less-affected countries sparked an infection in a hospital, which led to the second stage of the COVID-19 outbreak.

The second stage of the outbreak was from $7^{\text {th }}$ March to $22^{\text {nd }}$ April, when new cases were linked to a history of visiting, transitioning or returning from Europe, the USA and the Republic of Korea. ${ }^{20}$ A total of 252 cases over 22 provinces and cities were reported, of which 154 were imported cases $(61.1 \%) .{ }^{7}$ This time, the state deployed even stricter responses including border shutdown, an international travel ban to all countries, domestic travel restrictions, compulsory facemask use and national social distancing at work and public places. The Prime Minister declared the nationwide COVID-19 pandemic on $1^{\text {st }}$ April. ${ }^{21}$ According to the WHO's classification on COVID-19 transmission, Vietnam was classified as clusters of COVID-19 cases. Public health measures, therefore, were to "slow transmission and prevent the spread". ${ }^{22}$

The third stage of the outbreak was from $23^{\text {rd }}$ April until $19^{\text {th }}$ July when Vietnam managed to control the COVID-19 pandemic by eliminating community transmission. In this period, all cases (116) were imported and there were no deaths reported. The country gradually returned to normal as the strict regulations and curfews including social distancing, lockdown and domestic travel restrictions were lifted. The country re-opened the internal economy by the end of April 2020 (Figure 3).

\section{THE VIETNAMESE GOVERNMENT RESPONSES TO COVID-19}

\section{COORDINATION OF NATIONAL AND SUB-NATIONAL RESPONSES}

The Vietnamese government provided strong leadership in response to COVID-19 by establishing the National Steering Committee (NSC) led by Deputy Prime Minister - Vu Duc Dam. The NSC is a multi-ministerial and multisectoral committee, established on $30^{\text {th }}$ January - within a week of the first few cases being reported. ${ }^{23}$ The committee works to direct pandemic control and assessment on behalf of the government. The presence of key ministers and parties in the NSC enables it to make crucial decisions and systemically coordinate the implementation of containment measures. At local levels, 63 provincial and 707 district steering committees were established.

The Prime Minister promulgated the first Directive (No. 05/CT-TTg) on COVID-19 prevention and responses when Vietnam had only two imported COVID-19 cases. Importantly, the government initially chose a multi-sectoral approach and systemic response with careful risk assessment. ${ }^{5}$ Given that China and Vietnam share a long border and have a high flow of daily traffic, this initial step dramatically helped to control the potential spread of the virus to Vietnam. Further, to curb the local transmission, Vietnam immediately ordered rigid contact tracing and quarantine, cancellation of tours to and from COVID-19 affected regions and tight monitoring of incomers at all points of entry. ${ }^{5}$ By $30^{\text {th }}$ June, seven Directives on COVID-19 prevention and control (No. 05, 06, 11, 13, 15, 16 and 19/CT-TTg in sequence) were issued in alignment with the COVID-19 situation within the country. 


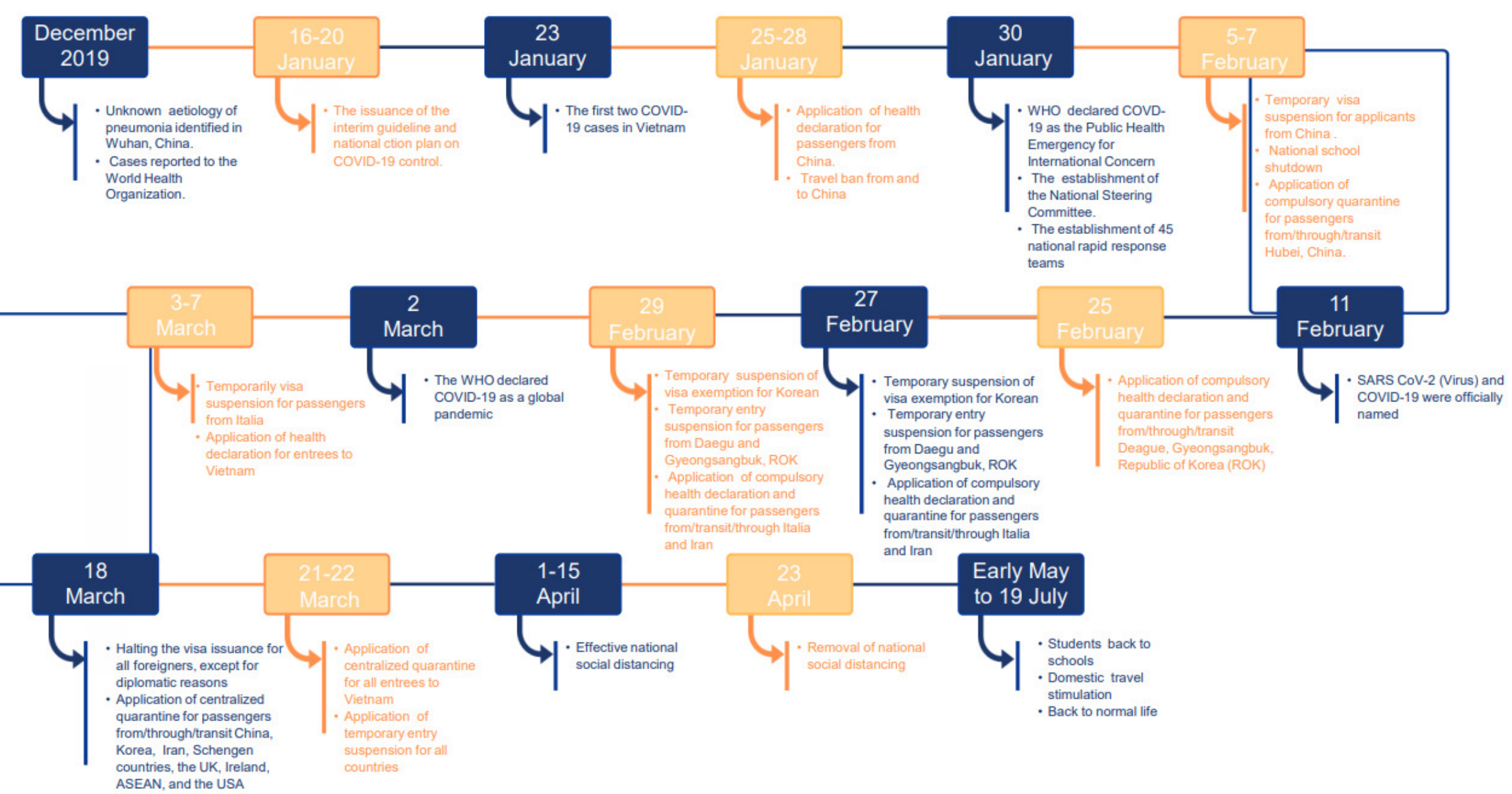

Figure 3. The timeline of the Vietnamese government responses to COVID-19. 
The $\mathrm{MoH}$ is the key player in the effort to coordinate COVID-19 containment measures among its sub-agencies and other ministries. It provides technical guidelines for prevention, treatment, surveillance and monitoring. The coordination of activities is mainly through official guidelines, letters or meetings led by the NSC. Noticeably, the $\mathrm{MoH}$ issued the first national interim guidelines for the diagnosis and treatment of COVID-19, and the national response plan with the four-plus COVID-19 response scenarios when Vietnam had no COVID-19 cases. The four-plus scenarios include - level 1: the disease penetrates the country; level 2: the infection is transmitted within the country; level 3: there are more than 20 cases identified within the country; and level 4: the disease is transmitted in the community with more than 1000 cases. ${ }^{23-25}$ The roles and responsibilities of other ministries in responding to COVID-19 were discussed elsewhere. ${ }^{8-10}$

\section{ENGAGEMENT AND MOBILIZATION OF AFFECTED AND AT-RISK COMMUNITIES}

Amidst the COVID-19 pandemic, effective risk communication is crucial to help at-risk people understand the situation and make informed decisions. This requires the provision of accurate information early and through channels and languages that people trust and understand. ${ }^{26}$

With regard to emergency risk communication, the $\mathrm{MoH}$ provided the comprehensive information on the COVID-19 situation internationally, nationally and regionally, and delivered information on preventative measures via official websites and various other means of media. ${ }^{7}$ Most of the key public health messages provided by the $\mathrm{MoH}$ were consistent with WHO's recommendations i.e. practicing personal hygiene and respiratory etiquette. ${ }^{27,28}$ The only difference was the compulsory use of a facemask. While the WHO did not recommend wearing a mask for healthy people or people without respiratory symptoms, ${ }^{29}$ the $\mathrm{MoH}$ took a more cautious approach, which saw the requirement escalate from optional to compulsory use to align with the rapidly changing COVID-19 situation. People were mandated to cover their faces in public places from $16^{\text {th }}$ March and when they went out during the social distancing period from $1^{\text {st }}$ to $30^{\text {th }}$ April. ${ }^{1,30,31}$ Financial penalties of 100,000 VND (USD 4.5) to 300,000 VND (USD 13) were applied to ensure adherence to the regulations.

Risk communication was a key strength of the Vietnamese response, as it leveraged both traditional media and new communication outlets such as mobile applications. Wide coverage of television, smartphone and mobile users (200 million mobile subscribers per 90 million population) made it easy for the Vietnamese government to reach out to its citizens. ${ }^{31}$ On $3^{\text {rd }}$ February, when Vietnam just had eight confirmed COVID-19 cases, SMS were sent to mobile users. ${ }^{6}$ Additionally, four mobile apps, namely SuckhoeVietnam, COVID-19, NCOVI and VietnamHealth, were developed during this period to serve the COVID-19 prevention strategy (Online Supplementary Document, Appendix 1). ${ }^{32-34}$

Vietnam's successful communication strategy catalyzes the active participation of both governmental and private sectors as well as communities. The government centers its people in an active role with the slogan translated as "every citizen is a soldier". In addition, nongovernment-led initiatives including the donation of funds and personal protection equipment by entrepreneurs and individuals have contributed positively to social stability. For example, "the rice ATM" - a free rice dispenser reserved for the most vulnerable people, including those who lost income due to the pandemic, the elderly, students and disabled people. ${ }^{35-37}$ Students have been mobilized to assist in epidemic control by engaging them in various roles such as data entry, sample collection or provision of phone counseling for COVID-19 suspected people. However, the number of students who joined the COVID-19 taskforce was very small (124 volunteer medical students) compared to its capacity. ${ }^{38}$ At the central level, a relief bill of approximately 80,600 VND billion was signed by the government to address the financial burden resulting from the COVID-19 pandemic. Nearly 62,000 VND billion of these funds were allocated to individuals who were poor, near poor, with meritorious services or under social protection schemes. The remaining funds were allocated to support small to medium production and business establishments. ${ }^{39}$

\section{IMPLEMENTATION OF CONTEXT-APPROPRIATE PUBLIC HEALTH MEASURES TO SLOW TRANSMISSION AND CONTROL SPORADIC CASES}

Consistent with WHO's recommendations, Vietnam administered contextualized critical public health measures to slow transmission of COVID-19 including strengthening the disease surveillance system, establishing a rapid response team, rigid monitoring at points of entry, strengthening of infection prevention and control strategies, applying mandatory health regulations, lockdown and movement restrictions (Figure 3).

SURVEILLANCE

Due to its limited resources, Vietnam deployed a strategy of early detection, isolation, contact tracing and quarantine instead of pursuing an extensive testing system. Rigorous investigation of epidemiological sources of patients and tracing of contacts has been employed from as early as $23^{\text {rd }}$ January. An initiative of voluntary and compulsory declaration of health at points of entry was promptly introduced. It was first applied on $26^{\text {th }}$ January for travelers from China, but was subsequently extended to all people entering Vietnam from $7^{\text {th }}$ March. ${ }^{40,41}$ This regulation was further expanded to domestic travelers travelling either by airplane or other public transport from $21^{\text {st }}$ March. ${ }^{42}$ The general public was encouraged to submit a voluntary health declaration, either online or via a mobile application named VietnamHealth to provide data for risk assessment and management. ${ }^{42}$ In April 2020, the WHO included this step in its guidelines. ${ }^{11}$ Vietnam produced COVID-19 rapid test, however, the country did not deploy mass testing as its capacity to produce only up to 10,000 test kits per day. ${ }^{43,44}$

To ease the process of case investigation, contact tracing and quarantine, Vietnam re-classified the definition of cases, suspected cases and close contacts (risk-carriers) with an application of the 'four rings of quarantine' system (Figure 4). ${ }^{27,45}$ People who carried a risk of coronavirus 


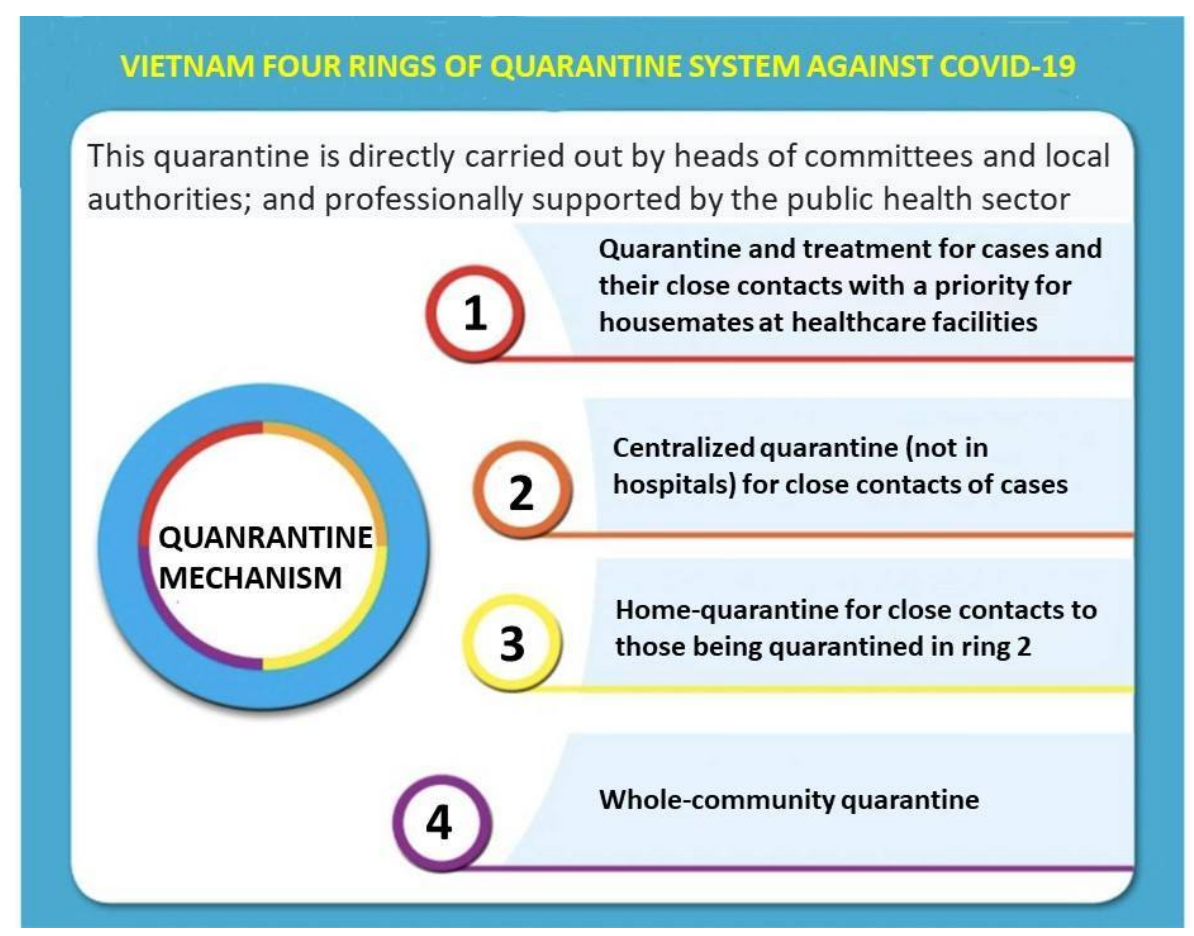

Figure 4. The "four rings" of the quarantine system against COVID-19 in Vietnam.

Figures was extracted from the Department of Health of Ho Chi Minh. It was developed based on the four rings of quarantine system which adapted successfully to the first outbreak in Viet Nam (Son Loi, Vinh Phuc, Viet Nam). Accessed 30 April 2020. Available: http://www.medinet.hochiminhcity.gov.vn/.

contamination were denoted as an " $F$ " and the length of quarantine varied from 14 to 28 days. F0 signified a confirmed positive case, while F1 was a close contact of a positive case, F2 was a close contact of F1 and F3 was a close contact of F2. ${ }^{27,46}$

The other significant contributor to effective COVID-19 surveillance was the success in combining both in vitro realtime reverse transcription-polymerase chain reaction (RTPCR) to confirm virus infection and serological test kits for the quick detection of SARS-CoV-2. ${ }^{47}$ These tests were developed by Vietnam Military Medical Institute and Viet A Joint Stock Company, which have widely used within the country to screen potential virus carriers. ${ }^{48}$ The test kit passed the Emergency Use Listing Procedure and was approved by the WHO in late April. ${ }^{48}$

To prepare for the potential spread of COVID-19, a total of 45 rapid response teams (RRT) were established on $30^{\text {th }}$ January. The RRT's missions included providing quick response and technical support for hospitals on the treatment of patients and control of infection at health facilities. ${ }^{49}$ At the local level, each Department of Health established two RRTs. Each RRT comprised a hospital leader, emergency resuscitation specialized doctor, infectious disease specialist, infectious disease control officer, emergency resuscitation or an infectious disease specialized nurse and a driver. ${ }^{49}$

BORDER CONTROL MEASURES

Vietnam applied strict measures to control the spread of infection at all points of entry (PoE) (land crossing points, seaports and airports). Three key authorities were involved in COVID-19 control at PoE including immigration officers (airports), soldiers (land crossing points or borders) and health officers who are trained appropriately on infection prevention and control (IPC) by relevant health authorities.

Regarding international travel restrictions or bans, the WHO produced inconsistent advice; on the $3^{\text {rd }}$ of February, the WHO initially suggested that travel restrictions may be useful to prevent the international spread of COVID-19, but later changed its guidance to "against an application of travel or trade restriction to COVID-19 affected countries" on $29^{\text {th }}$ February. ${ }^{50,51}$ In contrast, Vietnam maintained that the international travel restrictions from severely affected countries were a vital measure to curb the COVID-19. These restrictions were then extended to all countries on $22^{\text {nd }}$ March (Figure 3). ${ }^{52}$ At this point in time, Vietnam had only 94 cases and no reported deaths. ${ }^{53}$

INFECTION PREVENTION AND CONTROL (IPC)

IPC measures are essential to prevent cross-infection, not just for healthcare staff, but for others who are a part of the COVID-19 human resources. IPC should therefore be applied sufficiently at healthcare facilities at all levels, PoE and quarantine centers. ${ }^{11,12}$ Vietnam employed IPC measures effectively, with only two cross-infection cases reported in hospitals. Several guidelines to prevent infection and set up COVID-19 isolation units (in health facilities, at homes, quarantine centers and in hotels) were issued accordingly at an early stage of the pandemic. ${ }^{54-59}$ At PoE, IPC additionally followed the Law on infectious disease prevention and control (Decree 101/ND-CP). ${ }^{60}$ The government responded quickly to fill gaps in IPC when the first cases linked to malpractice in screening and triaging patients in hospitals were recorded by promptly issuing Letter 1385/BCDQG on strengthening IPC in hospitals. ${ }^{61}$ Since 
then, hospitals have generally had separate routes for patients with and without epidemiological factors and respiratory symptoms. ${ }^{61}$ IPC principles, in general, were consistent between the WHO guidelines and the MoH's response, except for their guidance on the use of facemasks. At the early stage of the outbreak, the WHO interim guidelines recommended that health workers at in-patient facilities were not required to use PPE if physical distancing was achieved, and that the use of a facemask was not necessary for patients without suspected COVID-19 symptoms. ${ }^{29}$ In contrast, these measures were mandated in Vietnam.

CURFEWS, RESTRICTIONS, AND LOCKDOWN

There are no universal guidelines for the application of curfews, restrictions, and lockdown measures from the WHO. Individual countries were to decide the level and scope of these measures based on their own situations and priorities. Of these measures, compulsory quarantine, visa suspension, border closure and social distancing were commonplace and were critical COVID-19 measures in Vietnam.

Apart from human international travel restrictions (PoE control section), Vietnam ordered restrictive domestic movement in March 2020, during the peak period of the first wave. For example, the tourism industry was closed in some areas from $9^{\text {th }}$ March and then nationally in April during the national social distancing period. ${ }^{62,63}$ Another strict measure was the school shutdown from $6^{\text {th }}$ February until early May. ${ }^{64}$ National social distancing was ordered on $28^{\text {th }}$ March when the country had a total of 171 cases and 8 new cases and was removed on $22^{\text {nd }}$ April when no new cases were reported within a week. ${ }^{7}$ Like many other countries, the social distancing order restricted most ordinary activities including un-serviced public transport and nonessential business activities. People were required to stay at home and work from home and going out was only allowed for essential activities such as buying food or medicine. ${ }^{19}$

Compared to social distancing, lockdown was more restrictive and people were not allowed to leave quarantine areas, which were defined and maintained by the Vietnam armed forces (full name here please), accompanied by the health teams. Health teams performed temperature checks twice a day and provided other urgent healthcare. Police ensured the safety of quarantine areas. The duration of quarantine varied by location but ranged between 14 and 28 days. Lockdown was normally ordered if a case was identified, and a lockdown could be applied regardless of the size of the area, from the smallest residential management unit (a building) to an entire district. ${ }^{27}$

\section{PROVISION OF CLINICAL CARE AND MAINTAINING OF ESSENTIAL HEALTH SERVICES TO REDUCE MORTALITY}

Per WHO's recommendations, Vietnam strengthened preventative measures at all levels and initially used telemedicine to monitor patients while reducing the risks of infection with COVID-19 for patients. ${ }^{12}$

According to the 2018 national census conducted by the General Statistics Office of Vietnam, there were 295,800 patient-beds (equivalent to $28 / 10,000$ inhabitants) and 84,800 doctors (equivalent to $8,6 / 10,000$ inhabitants). ${ }^{65}$ Thus, Vietnam applied rigorous public health measures (public health measure section) to reduce the burden on clinical care. Further, Vietnam's existing health system enabled the government to decentralize treatment for COVID-19 while maintaining its effectiveness. ${ }^{66-68}$

Provincial Centers for Disease Control (CDC) are focal points for the preventative medicine system. Vietnam has 47 central hospitals, 430 provincial or municipal hospitals, 1,030 district hospitals, $63 \mathrm{CDCs}, 500$ district health centers and 11,100 commune health stations. ${ }^{66}$ The private curative system has 231 hospitals at the central level and 35,000 health facilities at the local level. Hospitals are larger and more technologically advanced than health centers and health facilities. Central hospitals conduct research and have more advanced treatments available in key areas, and provide guidance and technical assistance to the local level. ${ }^{66}$ Currently, only the public health system provides COVID-19 treatments.

This decentralization of treatment reduces the unnecessary patient referrals and potential infection. It means that district hospitals are involved in the treatment of COVID-19 patients with a mild prognosis. Referral of patients were only applied for complicated COVID-19 cases. ${ }^{68}$ Treatment of patients followed the national guidelines in direct consultation with the rapid response teams. ${ }^{24}$ As per the WHO's recommendation, Vietnam postponed non-prioritized health services such as physiotherapy, immunization and health screening during the peak of the pandemic. ${ }^{69}$ Activities targeting the high-risk groups were implemented, including home-based medical examination, telemedicine and health management for the elderly and those with chronic health conditions. ${ }^{70,71}$

\section{ADOPTION OF STRATEGIES BASED ON RISK, CAPACITY AND VULNERABILITY}

Vietnam adopted strategies suitable for its economic circumstances, social structure and administrative management and health system. The country decentralized COVID-19 case management, treatment and IPC to reduce the burden on the clinical system (Figure 5). Control of sources of infection was contextualized in line with the functions of professional departments with cross-sectoral participation. Policies that directly targeted vulnerable groups made important contributions to ensuring the trust of the population and maintaining social stability. This is one of the likely reasons that contributed why the country's citizens responded simultaneously to government appeals and COVID-19 preventive measures.

A comparison of the COVID-19 control strategies used by the Vietnamese government and the WHO is described in Online Supplementary Document, Appendix 2.

\section{DISCUSSION}

To the best of our knowledge, this is among the first studiy to review the policies and state-led responses to COVID-19 in Vietnam, with reference to the WHO's recommended national strategies. We found that most measures were in compliance with the WHO guidelines. Notably, additional measures beyond the WHO's recommendations were also implemented, such as the introduction of travel restrictions 


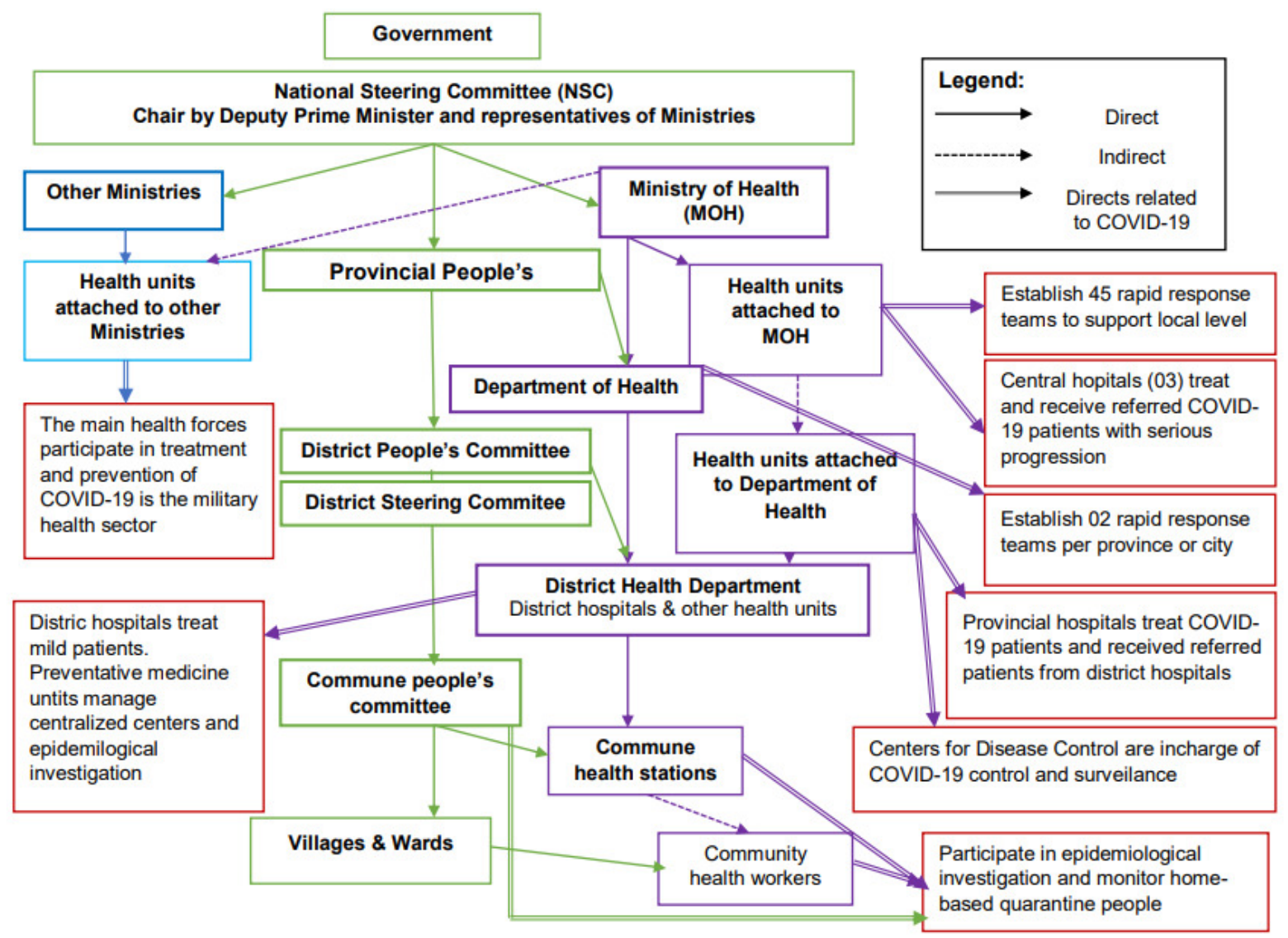

Figure 5. The COVID-19 management system within the Vietnamese health system.

and the mandated use of facemasks in public. We underlined four key factors that contributed strategically to slowing the spread of COVID-19 including strong leadership, timely responses, effective risk communication, community engagement, successful infection prevention and control, surveillance and rapid-test kit production. These factors worked collaboratively to ensure better outcomes.

Although some articles highlighted the early response and strong leadership of the Vietnamese government in responding to COVID-19, details of what these early responses were and the actions indicating the firm leadership seem to have been overlooked. ${ }^{8-11}$ Our study fills this gap by reviewing the actions and timelines of policies that the government deployed. It strengthens the view that strong leadership and early responses are the keys to successful COVID-19 control. ${ }^{8-11}$ This paper also found that the decisiveness of the government led to a quick and society-wide response, enabling the health system to prevent a health crisis. Taiwan and New Zealand shared a similar approach and both countries showed initial success. ${ }^{72,73}$ It took New Zealand only ten days to order a nationwide lockdown once the government observed an increasing trend of COVID-19 community transmission within the country. ${ }^{73}$ Swift actions and preparation for the predicted pandemic trend helped Vietnam to slow and contain the widespread of COVID-19. Slowing the disease outbreak is essential to pre- vent the surge and overwhelming of health facilities, where the demand for health care outweighs supply; a circumstance associated with increased mortality and morbidity. ${ }^{74}$ One of the factors that probably had substantial effect towards such a favorable response was experience from the SARS pandemic in 2003. This is of special importance as the Vietnamese healthcare system is improving, but it still has a limited capacity with an average of 8.6 doctors per 10,000 inhabitants and 28 patient beds per 10,000 inhabitants. ${ }^{65}$ Thus, a nationwide outbreak would certainly have challenged the country's health care system. ${ }^{66}$

Vietnam has also benefited from its policy of mandatory facemask use and the application of travel restrictions, which were not a part of the WHO's recommendations. The WHO changed its recommendations on face masks at crowded places for the general public where maintaining physical distancing is unachievable in June. ${ }^{75}$ A recent systemic review and meta-analysis indicated that physical distancing, face masks and eye protection are effective in preventing person-to-person transmission of COVID-19. ${ }^{76}$ The Center for Disease Control (CDC) in the USA recognized that wearing a mask prevents asymptomatic patients to transmit the virus to others. ${ }^{77}$ Given the successful evidence of mandatory mask use in Vietnam and China, around 50 countries around the world have since required people to "cover their faces when they leave homes" . ${ }^{78} \mathrm{Al}$ - 
though studies on the effectiveness of the early international travel restrictions are limited, results from our study and that of Chinazzi et al on the effect of travel restriction on mitigation of COVID-19, suggest that travel restriction combined with rigorous public measures and behavioral change can reduce the transmissibility of the coronavirus. ${ }^{79}$ Currently, many countries around the world have travel restrictions and travel bans in place.

Our findings suggest that the "fierce responses" of the Vietnamese government from the time of the outbreak in China inspired trust in the populous country of Vietnam. This is a cornerstone in enabling high-ranking leaders to make strategic decisions without major objections. Additionally, the one-party political institutions of Vietnam and its administrative management regime ensure that COVID-19 control orders and preventative measures are implemented systemically from the central to grassroots levels. For instance, the government decided that the need to combat the disease outweighed the economic costs of shutting down internal tourism, schools and international travel despite a relatively low number of cases identified within the country. Instead of drawing criticism, the government gained widespread support from its citizens, despite a huge projected economic loss due to the travel ban; between $\$ 5.9$ and $\$ 7$ billion was lost within three months (from March). ${ }^{80,81}$ Furthermore, the first nationwide partial lockdown showed impacts on individual life and work. Up to $61.6 \%$ of respondents reported their incomes were reduced, with the rate being higher among women. ${ }^{80}$ Both quality and quantity of work were drastically reduced while fear of stigmatization increased. ${ }^{82}$ The issues of anxiety and depression among people under the lockdown were reported in many countries including Vietnam. ${ }^{83-86}$

Effective emergency risk communication and community participation were an essential element of Vietnam's strategy against the pandemic. The aggressive communication campaign through official and non-official channels proved effective, though no studies were conducted to assess the awareness and practice of the general population regarding risk communication launched by the government. However, the country ranked top of 45 countries with regard to public trust in COVID-19 responses worldwide, based on an online survey conducted by Dalia. ${ }^{87}$ As opposed to China, which used an orthodox authoritarian style, Vietnam applied more transparent approaches in battling this pandemic. This is reflected in the way in which the government recognized the power of social networks and media to spread information and the transparency of the data while screening misleading information. ${ }^{88,89}$

Although there is insufficient evidence to conclude the relationship between public trust and its contribution to controlling COVID-19 based on this data, looking at the phenomenon in other Southeast Asian countries, there is an indication that transparent information led to better public trust and response to COVID-19. For example, public trust in COVID-19 information provided by the Vietnamese and Thai governments differed. Despite both countries recording their first cases at a similar time (January), at the time of writing this paper the number of COVID-19 cases in Thailand was almost seven times greater than in Vietnam. ${ }^{90}$ Similarly, Indonesians criticized their government for a lack of transparency and required more information and stronger responses against the COVID-19 crisis. ${ }^{91}$ The first case in Indonesia was confirmed on $2^{\text {nd }}$ March but escalated to 686 cases and 55 fatal cases within three weeks. ${ }^{90,91}$ This emphasizes that effective risk communication combined with strong risk management support is required to control COVID-19.

The involvement of communities in anti- pandemic work with the slogan "every citizen is a soldier" was a wise choice for the Vietnamese government. ${ }^{92}$ While the slogan may seem to be "propaganda", it had a positive effect. Without voluntary adherence to the recommended personal protection measures, the government would have struggled to reach its goals. Once again, media was the catalyst to promote community participation. Thus, to end the pandemic, the community must be a part of the solution and behavior change is key to stopping the spreading of the disease. ${ }^{26,91}$

Regarding medical supply assistance, it is worthy to note that Vietnam has a stable supply of masks from its garment industry, which strongly supports the mandatory facemask policy. Like many countries, Vietnam is also developing its own vaccines against COVID-19. Developed by Nanogen company, Vietnam Military Medical Academy, Nano Covax is the most promising candidate to date and is in the first stage of a trial. ${ }^{93}$ Without a vaccine, zero deaths in Vietnam by the end of the first wave of the pandemic is attributed to a successful formula combining effective IPC, surveillance and disease treatment. Successful IPC and surveillance, subsequently, contribute tremendously to reduce contact to COVID-19 risk bearers. The low number of infected cases minimized the burden on health facilities and frontline health staff in hospitals. During the first wave of the pandemic, vaccines had not approved for use on human, widespread testing was necessary to ease quarantine and isolation restrictions. ${ }^{94}$ With a high infection rate, a resurgence can happen in a matter of weeks. ${ }^{95}$ However, if a country can administer tests to detect COVID-19, process tests, track positive cases and conduct contact tracing rapidly, they have a good chance of gaining control of the pandemic. Timing is exceedingly important since many countries are "buying time" whilst waiting for a vaccine to battle the virus. ${ }^{96}$ The combination of both Real-time PCR test and quick serological test enabled Vietnam to suppress infection quickly.

By April, only five countries succeeded in manufacturing COVID-19 rapid tests, with the Republic of Korea leading the list. Korea deployed a massive testing system and aggressive approaching methods, with the test showing results in only ten minutes. ${ }^{43,96}$ This allowed life in Korea to return to normal. If Vietnam is a cost-effective model for low-middle income countries, Korea on the other hand is a promising model in dealing COVID-19 crisis for more open societies.

\section{LIMITATIONS}

As this study was a critical analysis of the responses of the Vietnamese government to the COVID pandemic up to $19^{\text {th }}$ July, the analysis is undertaken to the best knowledge of the authors according to the information gathered. This paper did not cover responses from the second wave of 
COVID-19 from 20 July with hotspots in Da Nang and Quang Nam since the governmental response strategies changed slightly with a focus on the local level. A separate review paper dedicated to this period will be needed. The authors acknowledge that trends and resources are likely to change with time, beyond the publication of this article. Further, as this analysis focused on health policy and overall health systems, other components of the health system that are not covered may also be important, such as health financing and quality of health services.

\section{CONCLUSIONS}

Our findings suggest that with limited resources, the adapted health system in Vietnam contributed to the successful containment of COVID-19 within the country. The firm leadership and political will of the government enabled the whole-society approach, which was critical to gain control of the pandemic. We recommend the application of travel restrictions and rigorous infection prevention and control should be put in place at the early stages of the pandemic. Travel restrictions may be eased once a country has successfully managed to control the spread of COVID-19.

\section{ACKNOWLEDGMENTS}

We would like to thank Mr. Philip Degenhardt, Rosa Luxemburg Stiftung, who gave valuable contributions in reviewing the draft of this manuscript.

\section{FUNDING}

This research project is financially supported by Rosa Luxemburg Stiftung. The content of the publication is the sole responsibility of authors (independent researchers) and does not necessarily reflect the position of Rosa Luxemburg Stiftung and their organizational affiliations.

\section{AUTHORSHIP CONTRIBUTIONS}

LTTT: Conceptualization, Methodology, Writing: original draft, review \& editing. EOM: visualization, Writing: original draft, review \& editing. DPV: Writing: review \& editing and visualization. MP: Visualization, Writing: review \& editing. RC: Writing: review \& editing. HN: Writing: review \& editing. DB: Writing: review \& editing, supervision.

\section{COMPETING INTERESTS}

The authors completed the Unified Competing Interest form at www.icmje.org/coi_disclosure.pdf (available upon request from the corresponding author), and declare no conflicts of interest.

\section{CORRESPONDENCE TO:}

\section{Luong Tran}

Migrant Health Project Officer

International Organization for Migration (IOM) Viet Nam

304 Kim Ma, Ba Dinh, Ha Noi, Viet Nam

ltttran@iom.int

Submitted: February 14, 2021 GMT, Accepted: March 16, 2021

GMT 


\section{REFERENCES}

1. Zhu N, Zhang D, Wang W, et al. A novel coronavirus from patients with pneumonia in China 2019. N Engl J Med. 2020;382(8):727-733. doi:10.1056/ nejmoa2001017

2. World Health Organization. Statement on the second meeting of the International Health Regulations (2005) Emergency Committee regarding the outbreak of novel coronavirus (2019-nCoV). Published online January 30, 2020. Accessed April 4, 2020. https://www.who.int/news-room/detail/30-01-2 020-statement-on-the-second-meeting-of-the-intern ational-health-regulations-(2005)-emergency-commi ttee-regarding-the-outbreak-of-novel-coronavirus-(2 019-ncov)

3. Word Health Organisation. WHO DirectorGeneral's opening remarks at the media briefing on COVID-19. Published online March 11, 2020. Accessed April 4, 2020. https://www.who.int/dg/speec hes/detail/who-director-general-s-opening-remarksat-the-media-briefing-on-covid-19---11-march-2020

4. Word Health Organization. Coronavirus disease (COVID-19): Situation Report - 162. Published online June 30, 2020. Accessed July 2, 2020. https://www.wh o.int/docs/default-source/coronaviruse/20200630-cov id-19-sitrep-162.pdf?sfvrsn=e00a5466_2

5. Prime Minister of Vietnam. Chỉ thị Số 05/CT-TTg Về việc phòng, chống dịch bệnh viêm đường hô hấp cấp do chủng mới của vi rút Corona gây ra [Directive number 05/CT-TTg about prevention and control acute respiratory disease caused by a novel coronavirus]. Accessed April 10, 2020. https://thuvien phapluat.vn/van-ban/the-thao-y-te/Chi-thi-05-CT-U BND-2020-day-manh-phong-chong-dich-Covid-19-ti nh-Ninh-Thuan-436338.aspx

6. Toàn cảnh các ca nhiễm Covid-19 tại Việt Nam tới ngày 12.3 [The complete picture of COVID-19 cases in Vietnam by 12 March 2020]. Thanh Nien. https://than hnien.vn/thoi-su/toan-canh-cac-ca-nhiem-covid-1 9-tai-viet-nam-toi-ngay-123-1194645.html. Accessed April 10, 2020.

7. General Department of Preventative Medicine. Tổ thông tin đáp ứng nhanh Ban chỉ đạo Quốc gia về Phòng chống dịch COVID-19 [Quick response information, National Steering Committee Responding to COVID-19]. Accessed July 30, 2020. htt ps://ncov.vncdc.gov.vn/pages/viet-nam-1.html
8. La VP, Pham TH, Ho MT, et al. Policy Response, Social Media and Science Journalism for the Sustainability of the Public Health System Amid the COVID-19 Outbreak: The Vietnam Lessons. Sustainability. 2020;12(7):2931. doi:10.3390/su120729 $\underline{31}$

9. Huynh TL. The COVID-19 risk perception: A survey on socioeconomics and media attention. Economics Bull. 2020;40(1):758-764.

10. Nguyen HT, Tran HN, Nguyen BV, et al. Outbreak investigation for COVID-19 in northern Vietnam. Lancet Infect Dis. 2020;5:535-536. doi:10.1016/s147 3-3099(20)30158-6

11. Tran BX, Hoang MT, Pham HQ, et al. The operational readiness capacities of the grassroots health system in responses to epidemics: Implications for COVID-19 control in Vietnam. Journal of Global Health. 2020;10(1). doi:10.7189/jog $\underline{\text { h.10.011006 }}$

12. Word Health Organisation. COVID - 19 strategy update. Published online April 14, 2020. Accessed May 2, 2020. https://www.who.int/publications-detai 1/covid-19-strategy-update---14-april-2020

13. World Bank. The World Bank In Vietnam: Overview 2020. Accessed April 27, 2020. https://ww w.worldbank.org/en/country/vietnam/overview

14. Health Policy Project. Health Financing Profile: Vietnam. Accessed May 10, 2020. https://www.health policyproject.com/pubs/7887/Vietnam HFP.pdf

15. Nguyen DT, Bui TMA, Chu HX, Hoang VM. Out-ofpocket health expenditures among insured and uninsured patients in Vietnam. Asia Pac J Public Health. 2020;31(3):210-218. doi:10.1177/1010539519 833549

16. Word Health Organization. Novel Coronavirus (2019-nCoV): situation report 03. Published online January 23, 2020. Accessed April 24, 2020. https://ww w.who.int/docs/default-source/coronaviruse/situatio n-reports/20200123-sitrep-3-2019-ncov.pdf?sfvrsn=d $\underline{6 \mathrm{~d} 23643 \_8}$

17. Prime Minister of Vietnam. Chỉ thị số 13/CT-TTg về việc tiếp tục đẩy mạnh phòng, chống dịch COVID-19 trong tình hình mới [Directive 13/CT-TTg on continuing COVID-19 prevention and control in the new situation]. Accessed April 14, 2020. https://th uvienphapluat.vn/van-ban/the-thao-y-te/Chi-thi-1 3-CT-TTg-2020-tiep-tuc-day-manh-phong-chong-dic h-COVID-19-trong-tinh-hinh-moi-436876.aspx 
18. Prime Minister of Vietnam. Chỉ thị số 15/CT-TTg của Thủ tướng Chính phủ về việc quyết liệt thực hiện đợt cao điểm phòng, chống dịch COVID-19 [Directive 15/CT-TTg on decisive implementation of COVID-19 prevention and control on the peak pandemic]. Accessed May 9, 2020. https://thuvienphapluat.vn/va n-ban/the-thao-y-te/Chi-thi-15-CT-TTg-2020-quyetliet-thuc-hien-dot-cao-diem-phong-chong-dich-COV ID-19-438342.aspx

19. Prime Minister of Vietnam. Chỉ thị số 16/CT-TTg về thực hiện các biện pháp cấp bách phòng, chống dich COVID-19 [Directive 16/CT-TTg on implementing urgent measures to prevent and control pandemic COVID-19]. Accessed May 1, 2020. https:/thuvienphapluat.vn/van-ban/The-thao-Y-te/C hi-thi-16-CT-TTg-2020-thuc-hien-bien-phap-cap-ba ch-phong-chong-dich-COVID-19-438648.aspx

20. Toàn cảnh dịch COVID-19 tới 24.3: Đe dọa sự lây lan trong cộng đồng [Overview of Covid-19 to 24.3 : Threatened to spread in the community]. Thanh Nien. https://thanhnien.vn/thoi-su/toan-canh-dich-covid-1 9-toi-243-de-doa-lay-lan-trong-cong-dong-120040 8.html. Accessed May 18, 2020.

21. Prime Minister of Vietnam. Quyết định số 447/ QĐ-TTg của Thủ tướng Chính phủ về việc công bố dịch COVID-19 [Decision No. 447/QD-TTg of the Prime Minister on the announcement of the COVID-19 pandemic]. Accessed May 18, 2020. http://vanban.chi nhphu.vn/portal/page/portal/chinhphu/hethongvanb an?class id=2\&mode=detail\&document $i d=199640$

22. Word Health Organisation. Operational considerations for case management of COVID-19 in health facility and community. Accessed April 14, 2020. https://apps.who.int/iris/bitstream/handle/1066 5/331492/WHO-2019-nCoV-HCF operations-202 0.1-eng.pdf

23. The Prime Minister of Vietnam. Quyết định 170 về việc thành lập Ban chỉ đạo quốc gia phòng chống bệnh viêm đường hô hấp cấp do chủng mới corona vi rút gây ra [Decision No. 170/QD-TTg on establishing the National Steering Committee for prevention and control of acute respiratory infections caused by a new strain of Corona virus]. Accessed April 14, 2020. http://vanban.chinhphu.vn/portal/page/portal/chinhp hu/hethongvanban?class_id=2\&_page $=1 \&$ mode $=$ detai 1\&document_id=198963

24. Ministry of Health. Quyêt định 125/QĐ-BYT về việc Hướng dẫn Chẩn đoán và điều trị bệnh viêm phổi cấp do chủng virut Corona mới (nCoV) [Decision No. 125/QD-BYT promulgating the guidelines for the diagnosis and treatment of acute pneumonia caused by new strain of Corona virus (nCoV)]. Accessed April 16, 2020. https://thuvienphapluat.vn/van-ban/the-th ao-y-te/Ouyet-dinh-125-OD-BYT-2020-Chan-doan-v a-dieu-tri-benh-viem-phoi-cap-do-chung-vi-rut-Cor ona-moi-433264.aspx
25. The Ministry of Health. Quyết đinh 156 về việc ban hành kế hoạch đáp ứng với bệnh viêm phổi cấp do chủng mới của vi rút corona [Decision No. 156/QDBYT on issuing the response plan to acute pneumonia caused by new strain of corona virus]. Published online 2020. Accessed April 16, 2020. https://thuvien phapluat.vn/van-ban/the-thao-y-te/Quyet-dinh-15 6-QD-BYT-2020-Ke-hoach-dap-ung-voi-benh-viemphoi-cap-do-chung-vi-rut-Corona-433464.aspx

26. Word Health Organisation. Communicating Risk in Public Health Emergencies: A WHO Guideline for Emergency Risk Communication (ERC) policy and practice. Accessed April 14, 2020. https://www.who.in t/risk-communication/guidance/download/en/

27. The Ministry of Health. Quyết đinh 963/QĐ-BYT về việc ban hành "hướng dẫn tạm thời giám sát và phòng, chống covid-19” [Decision No. 963/QD-BYT on promulgating "Temporary guidance on supervision and prevention of COVID-19"]. Published online 2020. Accessed April 17, 2020. https://thuvienp hapluat.vn/van-ban/the-thao-y-te/Quyet-dinh-963-Q D-BYT-2020-Huong-dan-tam-thoi-giam-sat-va-phon g-chong-COVID-19-437400.aspx

28. World Health Organization. Coronavirus disease (COVID-19) advice for the public. Accessed May 18, 2020. https://www.who.int/emergencies/diseases/nov el-coronavirus-2019/advice-for-public

29. World Health Organization. Rational use of personal protective equipment for coronavirus disease (COVID-19) and considerations during severe shortages. Accessed July 17, 2020. https://www.who.in $\mathrm{t}$ /publications/i/item/rational-use-of-personal-protec tive-equipment-for-coronavirus-disease-(covid-19)-a nd-considerations-during-severe-shortages

30. The Airport Corporation of Vietnam. Chỉ thị của Tổng Giám đốc Tổng công ty Cảng hàng không Việt Nam về việc đeo khẩu trang tại các Cảng hàng không, nơi làm việc [Directive of the General Director of Vietnam Airport Corporation on wearing masks at airports and workplaces]. Accessed May 18, 2020. http s://www.vietnamairport.vn/tin-tuc/tin-tuc-hoat-don g-tong-cong-ty/chi-thi-cua-tong-giam-doc-tong-con g-ty-cang-hang-khong-viet-nam-ve-viec-trien-khainhiem-vu-theo-yeu-cau-cua-ban-chi-dao-quoc-gia-p hong-chong-dich-benh-covid-19-bo-giao-thong-va n-tai

31. The Ministry of Health. 28 tỉnh, thành phố tiếp tục thực hiện Chỉ thị 16/CT-TTg [28 provinces and cities continue to implement Directive 16/CT-TTg]. Accessed May 28, 2020. https://moh.gov.vn/hoat-don g-cua-lanh-dao-bo/-/asset publisher/TW6LTp1Ztwa N/content/28-tinh-thanh-pho-tiep-tuc-thuc-hien-ch i-thi-16-ct-ttg 
32. Hỗ trợ báo chí tối đa trong tuyên truyền phòng chống dịch Covid-19 [Maximum press support in advocacy and prevention of the COVID-19 pandemic]. ICT Viet Nam. Accessed May 18, 2020. http://ictvietna m.vn/ho-tro-bao-chi-toi-da-trong-tuyen-truyen-pho ng-chong-dich-covid-19-20200319092433271.htm

33. Thuy H. Bộ Y tế ra mắt app Sức khỏe Việt Nam về dịch do virus corona [The Ministry of Health has launched the Vietnam Health app about the disease caused by corona virus]. ICT Vietnam. Accessed June 2, 2020. http://ictvietnam.vn/ho-tro-bao-chi-toi-da-t rong-tuyen-truyen-phong-chong-dich-covid-19-2020 0319092433271.htm

34. Ministry of Health. Phòng dịch COVID-19: ra mắt ứng dụng trợ giúp y tế cho người Việt Nam và người nước ngoài [COVID-19 pandemic prevention: launched medical assistance application for Vietnamese and foreigners]. Accessed May 18, 2020. $\underline{\mathrm{h}}$ ttps://ncov.moh.gov.vn/-/ra-mat-ung-dung-tro-giupy-te-cho-nguoi-viet-nam-va-nguoi-nuoc-ngoai

35. Rice ATM' Feeds Vietnam's Poor Amid Virus Lockdown. US News. https://www.usnews.com/news/ world/articles/2020-04-13/rice-atm-feeds-vietnams-p oor-amid-virus-lockdown. Published April 13, 2020. Accessed June 7, 2020.

36. Trend "Rice ATMs" dispense hopes to Vietnam's poor. VN Express. Accessed June 16, 2020. https://e.vn express.net/news/life/trend/rice-atms-dispense-hop e-to-vietnam-s-poor-4084369.html

37. Hơn 40 tỷ đồng ủng hộ phòng chống dịch Covid-19 qua Cổng nhân đạo 1407 [Over 40 billion VND in support of the prevention of COVID-19 pandemic through Humanitarian Portal 1407]. Vietnamnet. Accessed June 8, 2020. https://vietnamnet.vn/vn/thon g-tin-truyen-thong/hon-30-ty-dong-ung-ho-phong-c hong-dich-covid-19-qua-cong-nhan-dao-1407-62581 $\underline{3 . h t m l}$

38. Tran BX, Vo LH, Phan HT, et al. Mobilizing medical students for COVID-19 responses: Experience of Vietnam. Journal of Global Health. 2020;10(2). doi:1 $\underline{0.7189 / j o g h .10 .020319}$

39. Đề xuất gói hỗ trợ lần 2: 18,600 tỉ cho người lao động và doanh nghiệp bị ảnh hưởng vì COVID-19 [The proposed second support package for employees and businesses affacted by COVID-19]. Tuoi Tre. https://th uvienphapluat.vn/tintuc/vn/thoi-su-phap-luat/thoi-s u/30709/de-xuat-goi-ho-tro-lan-2-18-600-ti-cho-ngu oi-lao-dong-doanh-nghiep-bi-anh-huong-vi-covid-1 9. Accessed January 10, 2021.
40. The Ministry of Health. Công văn 357/BYT-DP áp dụng tờ khai y tế tại cửa khẩu' [Dispatch No. 357/BYTDP on applying medical declarations at the borders]. Accessed March 20, 2020. https://moh.gov.vn/docume nts/176127/356256/24.01.2020.CV+357+BYT-DP.pdf/a 7c825b6-4a15-42c3-bc9b-3a89c3de2e00

41. The Ministry of Health. Văn bản 1119/BYT-DP về việc thực hiện áp dụng khai báo y tế đối với COVID-19 [Dispatch 1119/BYT-DP on applying health declaration to COVID-19]. Published online 2020. Accessed June 6, 2020. https://thuvienphapluat.vn/co ng-van/the-thao-y-te/Cong-van-1119-BYT-DP-202 0-thuc-hien-ap-dung-khai-bao-y-te-doi-voi-COVI D-19-436636.aspx

42. Minister of Ministry of Transport. Công văn số 2594/BGTVT-CYT về việc khai báo y tế băt buộc trên các chuyển bay nội địa và phương tiện giao thông công cộng [Dispatch No. 2594/BGTVT-CYT on compulsory medical declaration on domestic flights and public transport]. Accessed June 18, 2020. http s://thuvienphapluat.vn/cong-van/giao-thong-van-tai/ Cong-van-2594-BGTVT-CYT-2020-khai-bao-y-te-ba t-buoc-tren-chuyen-bay-phuong-tien-cong-cong-437 985.aspx

43. Hochiminh Department of Health. Tóm lược thông tin về triển khai test nhanh COVID-19 tại Hà Nội trong thời gian qua [Summary of information on implementing quick test COVID-19 in Hanoi recently]. Accessed June 10, 2020. http://www.medine t.hochiminhcity.gov.vn/tin-tuc-su-kien/tom-luoc-tho ng-tin-ve-trien-khai-test-nhanh-covid-19-tai-ha-no i-trong-thoi-gian-cmobile1780-27153.aspx

44. Việt Nam công bố có thể sản xuất 10,000 bộ kít phát hiện nCoV/ngày [Vietnam announced that the country could produce 10,000 sets of nCoV detection kets per day]. Nhan Dan. https://nhandan.com.vn/kho a-hoc/viet-nam-cong-bo-co-the-san-xuat-10-000-b o-kit-phat-hien-ncov-ngay-451172/. Accessed August 20, 2020.

45. The Ministry of Health. Công văn 1338/CVBCĐQD về việc tổ chức cách ly người nhập cảnh từ quốc gia, vùng lãnh thổ có dịch COVID-19 [Dispatch 1338/BCDQD on the organization of isolation of people entering from countries and territories with COVID-19 outbreaks]. Accessed May 10, 2020. http s://thuvienphapluat.vn/cong-van/the-thao-y-te/Con g-van-1338-CV-BCD-2020-cach-ly-nguoi-nhap-can h-tu-quoc-gia-vung-lanh-tho-co-dich-COVID-19-437 578.aspx 
46. The Ministry of Health. Quyết định số 343/QĐBYT về việc ban hành "Hướng dẫn tạm thời giám sát và phòng, chống bệnh viêm đường hô hấp cấp do chủng mới của vi rút Corona (nCoV) [Decision No. 343/QD-BYT on the promulgation of "Guidelines for temporary monitoring and prevention of acute respiratory infections caused by new strains of Corona virus (nCoV)]. Accessed March 10, 2020. http s://moh.gov.vn/documents/176127/356256/07.02.202 0+343+Q\%C4\%90-BYT_.pdf/66be675f-520a-4f20-849 c-1796d8130d9a

47. Hoang XS, Dinh TH, Nguyen TS, Hoang VL. The Ministry of Science and Technology launches the announcement of in vitro real-time RT-PCR kit product for detection of SARDS-CoV-2 approved by the Ministry of Health, Vietnam. Accessed April 18, 2020. https://www.researchgate.net/publication/3397 70843 the ministry of science and technology_launc hed the announcement of in vitro_real-time_rt-pc r kit_product for_detection_of_sars-cov-2_approved f $\mathrm{f}$ rom_ministry_of_health_vietnam

48. WHO approves made-in-Vietnam Covid-19 test kit Hanoi. VNEXPRESS. Accessed April 29, 2020. http s://e.vnexpress.net/news/news/who-approves-made-i n-vietnam-covid-19-test-kit-4090402.html

49. The Ministry of Health. Quyết định số 225/QĐBYT về việc thành lập Đội cơ động phản ứng nhanh chống dịch viêm đường hô hấp cấp do chủng mới của vi rút Corona (nCoV) [Decision No. 225/QD-BYT on the establishment of rapid response teams to quickly respond to acute respiratory infections caused by a new strain of Corona virus (nCoV)]. Accessed July 8, 2020. http://vncdc.gov.vn/vi/phong-chong-dich-ben h-viem-phoi-cap-ncov/8621/quyet-dinh-so-225-qd-b yt-ngay-30-1-2019-bo-y-te-da-thanh-lap-thanh-la p-45-doi-co-dong-phan-ung-nhanh-chong-dich-vie m-duong-ho-hap-cap-do-virus-ncov

50. Word Health Organisation. 2019 Novel

Coronavirus (2019-nCoV): Strategic preparedness and response plan. Accessed May 15, 2020. https://www.w ho.int/publications-detail/strategic-preparedness-an d-response-plan-for-the-new-coronavirus

51. Word Health Organisation. Updated WHO advice for international traffic in relation to the outbreak of the novel coronavirus 2019-nCoV. Accessed April 18, 2020. https://www.who.int/news-room/articles-detai 1/updated-who-advice-for-international-traffic-in-rel ation-to-the-outbreak-of-the-novel-coronavirus-201 9-ncov-24-jan/
52. The Ministry of Transportation. Văn bản số 2596/ BGTVT-VT tiếp tục thực hiện kết luận của Thủ tướng Chính phủ theo Thông báo số 118/TB-VPCP của Văn phòng Chính phủ [Letter No. 2596/BGTVT-VT on continuing to implement the conclusions of the Prime Minister in Notice No. 118/TB-VPCP of the Government Office]. Accessed April 14, 2020. http s://www.mt.gov.vn/Images/editor/files/Hoa/2020/259 61signed.pdf

53. Word Health Organisation. Coronavirus disease 2019 (COVID-19) Situation Report-62. Published online March 22, 2020. Accessed April 14, 2020. http s://www.who.int/docs/default-source/coronaviruse/sit uation-reports/20200322-sitrep-62-covid-19.pdf?sfvr $\underline{\mathrm{sn}}=755 \mathrm{c} 76 \mathrm{~cd} 2$

54. The Ministry of Health. Quyết định số 1551/QĐBYT Hướng dẫn cách ly y tế tại các cơ sở khám, chữa bệnh [Decision No. 1551/QD-BYT on the guideline on health quarantine at health facilities]. Accessed April 10, 2020. https://thuvienphapluat.vn/van-ban/the-th ao-y-te/Quyet-dinh-1551-QD-BYT-2020-Huong-dancach-ly-y-te-tai-co-so-kham-chua-benh-phong-COV ID-19-439036.aspx

55. The Ministry of Health. Quyết định số 468/QĐBYT về việc Ban hành hành hướng dẫn kiểm soát lây nhiễm bệnh viêm đường hô hấp cấp do corona 19 (COVID-19) trong các cơ sở khám bệnh, chữa bệnh [Decision 468/QD-BYT on promogating guidelines on COVID-19 prevention and control in health facilities]. Accessed April 10, 2020. https://thuvienphapluat.vn/v an-ban/the-thao-y-te/Ouyet-dinh-468-OD-BYT-202 0-phong-kiem-soat-lay-nhiem-benh-viem-duong-h o-hap-cap-vi-rut-Corona-434918.aspx

56. The Ministry of Health. Quyết định 1246/QĐ-BYT về việc ban hành “Hướng dẫn tạm thời cách ly y tế tập trung tại khách sạn trong phòng, chống dịch COVID-19 do người được cách ly tự nguyện chi trả” [Decision 1246/QD-BYT on issuing 58. "Temporary guidance on concentrated medical isolation at hotels in prevention and control of COVID-19 with voluntary payment by isolated people"]. Accessed July 7, 2020. https://moh.gov.vn/documents/176127/35625 6/20.3.2020+1246-O\%C4\%90-BYT.pdf/5db68c19-532 9-4717-80e6-0a259f5b47f5

57. The Ministry of Health. Quyết định số 344/QĐBYT về việc ban hành "Hướng dẫn cách ly y tế tại cơ sở cách ly tập trung để phòng chống dịch bệnh viêm đường hô hấp cấp do chủng mới của vi rút Corona (nCoV)" [Decision No. 344/QD-BYT on promulgating the "Guidance on centralized quarantine for the prevention of acute respiratory infections caused by new strains of Corona virus (nCoV)"]. Accessed March 15, 2020. https://moh.gov.vn/documents/176127/356 256/07.02.2020+344+O\%C4\%90-BYT.pdf/aef543f8-fd3 7-46ba-b8e9-6b4b7e1aded3 
58. The Ministry of Health. Quyết định số 345/QĐBYT về việc ban hành "Hướng dẫn cách ly y tế tại nhà, nơi lưu trú để phòng chống bệnh viêm đường hô hấp cấp do chủng mới của vi rút Corona (nCoV) [Decision 345/QD-BYT on promulgating the "Guidance on at home-based quarantine for the prevention of acute respiratory infections caused by new strains of Corona virus (nCoV) "]. Accessed April 14, 2020. http s://moh.gov.vn/documents/176127/356256/07.02.202 0+345+Q\%C4\%90-BYT.pdf/a9333895-a886-46c3-bd6 c-da3c7c08950f

59. The Ministry of Health. Quyết định số 181/QĐBYT về việc ban hành "Hướng dẫn tạm thời giám sát và phòng, chống bệnh viêm đường hô hấp cấp do chủng mới của vi rút Corona (nCoV)" [Decision 181/ QD-BYT on promulgating "Interim guidance on the prevention and control of acute respiratory infections caused by new strains of Corona virus (nCoV)"]. Accessed March 17, 2020. https://moh.gov.vn/docume nts $/ 176127 / 356256 / 21.01 .2020+181+Q \% C 4 \% 90-B Y$ T.pdf/b974d070-df28-49e9-b988-15e926967af1

60. Prime Minister. Nghị định số 101/2010/NĐ-CP của Chính phủ: Quy định chi tiết thi hành một số điều của Luật Phòng, chống bệnh truyền nhiễm về áp dụng biện pháp cách ly y tế, cưỡng chế cách ly y tế và chống dịch đặc thù trong thời gian có dịch [Decree No. 101/2010/ ND-CP of the Government: detailing the implementation of articles of the Law on Prevention and Control of Infectious Diseases regarding the application of health quarantine, enforcement of health quarantine and prevention of pandemics during pandemic periods]. Accessed March 25, 2020. $\underline{\mathrm{h}}$ ttps://thuvienphapluat.vn/van-ban/the-thao-y-te/ $\mathrm{Ng}$ hi-dinh-101-2010-ND-CP-huong-dan-Luat-phong-ch ong-benh-truyen-nhiem-112597.aspx

61. The Ministry of Health. Công văn 1385/BCĐQG về việc rút kinh nghiệm tổ chức phân luồng, cách ly người nghi viêm đường hô hấp tại CSYT và gửi hình ảnh đã thực hiện [Letter 1385/BCĐQG on learning from experience in triage people with suspected respiratory infections at health facilities and sending the implemented pictures]. Accessed April 15, 2020. $\underline{\mathrm{h}}$ ttps://kcb.vn/wp-content/uploads/2020/11/CV-huon g-dan-phan-luong-NB-Covid.pdf

62. Lo ngại dịch COVID-19, nhiều điểm du lịch tạm dừng đón khách [Concerned about the outbreak of COVID-19, many tourist sites stopped to welcome visitors]. The Government Press. http://baochinhphu.v n/Du-lich/Lo-ngai-dich-COVID19-nhieu-diem-du-lic h-tam-dung-don-khach/389595.vgp. Accessed May 8, 2020.

63. Thêm nhiều tỉnh tạm đóng cửa các điểm du lịch [More provinces temporarily close tourist sites]. VGP News. http://baochinhphu.vn/Du-lich/Them-nhieu-ti nh-tam-dong-cua-cac-diem-du-lich/389814.vgp. Accessed April 4, 2020.
64. Cập nhật mới nhất: Lịch đi học trở lại của học sinh, sinh viên 63 tỉnh thành [Latest update: Returning school schedule of students in 63 provinces]. Kenh 14. Accessed May 15, 2020. https://kenh14.vn/cap-nhatmoi-nhat-lich-di-hoc-tro-lai-cua-hoc-sinh-sinh-vie n-63-tinh-thanh-20200425092719376.chn

\section{General Statistic Office of Vietnam. Statistical} Summary Book of Vietnam.; 2019.

66. Nguyen VH, Hoang VM, Dao ATM, et al. An adaptive model of health system organization and responses helped Vietnam to successfully halt the Covid - 19 pandemic: What lessons can be learned from a resource - constrained country. Int J Health Plann Mgmt. 2020;35(5):988-992. doi:10.1002/hpm.30 $\underline{04}$

67. The Ministry of Health. Đại cương Hệ thống Y tế và Tổ chức mạng lưới Y tế Việt Nam [Health System Overview and Vietnam Health Network Organization]. Accessed May 25, 2020. https://healthv ietnam.vn/thu-vien/tai-lieu-tieng-viet/to-chuc-quanly-y-te/dai-cuong-ve-he-thong-y-te-va-to-chuc-man g-luoi-y-te-viet-nam

68. The Ministry of Health. Bộ Y tế phân tuyến điều trị bệnh nCoV [Ministry of Health decentralizes treatment for COVID-19]. Accessed May 25, 2020. htt ps://moh.gov.vn/thong-tin-chi-dao-dieu-hanh/-/asse t_publisher/DOHhlnDN87WZ/content/bo-y-te-phan-t uyen-ieu-tri-benh-ncov

69. Từ 30.3, Bệnh viện Chợ Rẫy tạm ngưng hoạt động một số khoa khám bệnh [From March 30, Cho Ray Hospital suspended operations of several medical examination departments]. Thanh Nien. https://thanh nien.vn/thoi-su/tu-303-benh-vien-cho-ray-tam-ngun g-hoat-dong-mot-so-khoa-kham-benh-1203061.htm 1. Accessed April 9, 2020.

70. The Ministry of Health. Quyết định 1588/QĐ-BYT về “Hướng dẫn tạm thời quản lý sức khỏe người cao tuổi, người mắc bệnh mạn tính tại tuyến y tế cơ sở trong bối cảnh dịch Covid-19" và "Hướng dẫn chăm sóc sức khỏe phòng chống dịch Covid-19 cho người cao tuổi tại cộng đồng” [Decision 1588/QD-BYT on "Guidelines for temporary management of the health of the elderly and people with chronic diseases at the grassroots level in the context of the COVID-19 pandemic" and "Guidelines for health care and prevention of COVID-19 for the elderly in the community "]. Accessed June 20, 2020. https://luatvie tnam.vn/y-te/quyet-dinh-1588-qd-byt-huong-dan-qu an-ly-suc-khoe-nguoi-cao-tuoi-thoi-diem-dich-covi d-182272-d1.html

71. Tran BX, Hoang MT, Vo LH, et al. Telemedicine in the COVID-19 pandemic: Motivations for integrated, interconnected, and community-based health delivery in resource-scarce settings? Front Psychiatry. 2020;11. doi:10.3389/fpsyt.2020.564452 
72. Vietnam shows how you can contain COVID-19 with limited resources. World Economic Forum. Published online March 2020. Accessed April 18, 2020. https://www.weforum.org/agenda/2020/03/viet nam-contain-covid-19-limited-resources/

73. Baker MG, Wilson N, Anglemyer A. Successful elimination of covid-19 transmission in New Zealand. N Engl J Med. 2020;383(8):e56. doi:10.1056/nejmc202 $\underline{5203}$

74. Cavallo JJ, Donoho DA, Forman HP. Hospital Capacity and Operations in the Coronavirus Disease 2019 (COVID-19) Pandemic-Planning for the Nth Patient. JAMA Health Forum. 2020;1(3):e200345. doi:1 0.1001/jamahealthforum.2020.0345

75. World Health Organization. Advise on the use of masks in the contetxt of COVID-19. Accessed July 7, 2020. https://www.who.int/publications/i/item/advic e-on-the-use-of-masks-in-the-community-during-ho me-care-and-in-healthcare-settings-in-the-contextof-the-novel-coronavirus-(2019-ncov)-outbreak

76. Chu DK, Akl EA, Duda S, et al. Physical distancing, face masks, and eye protection to prevent person-to-person transmission of SARS-CoV-2 and COVID-19: A systematic review and meta-analysis. The Lancet. 2020;395(10242):1973-1987. doi:10.1016/ s0140-6736(20)31142-9

77. Center for Disease Control. Recommendation Regarding the Use of Cloth Face Coverings, Especially in Areas of Significant Community-Based

Transmission. Accessed April 15, 2020. https://www.c dc.gov/coronavirus/2019-ncov/prevent-getting-sick/cl oth-face-cover.html

78. Which countries have made wearing face masks compulsory? ALJAZEERA. Published online April 2020. Accessed June 8, 2020. https://www.aljazeera.co $\mathrm{m} /$ news/2020/04/countries-wearing-face-masks-com pulsory-200423094510867.html

79. Chinazzi M, Davis JT, Ajelli M, et al. The effect of travel restrictions on the spread of the 2019 novel coronavirus (COVID-19) outbreak. Science. 2020;368(6489):395-400. doi:10.1126/science.aba975 7

80. Vietnam's Coronavirus Struggle: Managing the Economic Impact. The Diplomat. Published online March 2020. Accessed May 9, 2020. https://thediplom at.com/2020/03/vietnams-coronavirus-struggle-mana ging-the-economic-impact/

81. Vietnam's Communist Party Finds a Silver Lining in COVID-19. The Diplomat. Accessed June 6, 2020. ht tps://thediplomat.com/2020/03/vietnams-communis t-party-finds-a-silver-lining-in-covid-19/
82. Dang AK, Le XTT, Le HT, et al. Evidence of COVID-19 impacts on occupations during the first Vietnamese national Lockdown. Annals of global health. 2020;86(1). doi:10.5334/aogh.2976

83. Le XTT, Dang AK, Toweh J, et al. Evaluating the psychological impacts related to COVID-19 of Vietnamese people under the first Nationwide partial lockdown in Vietnam. Front Psychiatry. 2020;11(824). doi:10.3389/fpsyt.2020.00824

84. Le HT, Lai AJX, Sun J, et al. Anxiety and depression among people under the nationwide partial lockdown of Vietnam. Front Public Health. 2020;8(656). doi:10.3389/fpubh.2020.589359

85. Lee SA, Jobe MC, Mathis AA, Gibbons JA. Incremental validity of coronaphobia: Coronavirus anxiety explains depression, generalized anxiety, and death anxiety. Journal of Anxiety Disorders. 2020;74:102268. doi:10.1016/j.janxdis.2020.102268

86. Nie XD, Wang Q, Wang MN, et al. Anxiety and depression and its correlates in patients with coronavirus disease 2019 in Wuhan. International Journal of Psychiatry in Clinical Practice. Published online July 14, 2020:1-6. doi:10.1080/13651501.202 $\underline{0.1791345}$

87. Dalia. Global study about COVID-19: Dalia assesses how the world ranks their governments' response to the pandemic. Published online 2020. Accessed July 18, 2020. https://daliaresearch.com/blo $\mathrm{g} /$ dalia-assesses-how-the-world-ranks-their-governm ents-response-to-covid-19/

88. Lowy Institute. Vietnam, North Korea, politics and Covid-19: The numbers tell a story. Accessed June 10, 2020. https://www.lowyinstitute.org/the-interpret er/vietnam-north-korea-politics-and-covid-19-numb ers-tell-story

89. Green A. Li wenliang. The Lancet. 2020;395(10225):682. doi:10.1016/s0140-6736(20)303 $\underline{82-2}$

90. Word Health Organisation. Coronavirus disease 2019 (COVID-19) Situation Report - 65. Accessed June 6, 2020. https://www.who.int/docs/default-sourc e/coronaviruse/situation-reports/20200325-sitrep-6 5-covid-19.pdf?sfvrsn=ce13061b_2

91. Djalante R, Lassa J, Setiamarga D, et al. Review and analysis of current responses to COVID-19 in Indonesia: Period of January to March 2020. Progress in Disaster Science. 2020;6:100091. doi:10.1016/j.pdis as.2020.100091 
92. Mỗi người dân là một chiến sĩ!' [Each citizen is a soldier]. Nhan Dan. https://nhandan.com.vn/chinhtri/ item/43867202-moi-nguoi-dan-la-mot-chien-si.html. Accessed June 27, 2020.

93. Ministry of Health. Ngày mai Việt Nam sẽ tiêm Vaccine COVID-19 liều cao nhất cho tình nguyện viên [Vietnam will trial the highest dose of COVID-19 vaccine for volunteers]. Accessed January 12, 2021. ht tps://ncov.moh.gov.vn/web/guest/-/6847426-724

94. OECD. Testing for COVID-19: A way to lift confinement restrictions. Accessed June 10, 2020. htt ps://www.oecd.org/coronavirus/policy-responses/test ing-for-covid-19-a-way-to-lift-confinement-restrictio ns-89756248/
95. Hollingsworth TD, Ferguson NM, Anderson RM. Travelers and rate of spread of pandemics. Emerg Infect Dis. 2020;13(9):1288-1294. doi:10.3201/eid130 $\underline{9.070081}$

96. Seoul's Full Cafes, Apple Store Lines Show Mass Testing Success. Bloomberg. https://www.bloomberg.c om/news/articles/2020-04-18/seoul-s-full-cafes-appl e-store-lines-show-mass-testing-success. Published April 18, 2020. Accessed June 10, 2020. 


\section{SUPPLEMENTARY MATERIALS}

\section{Appendix 1}

Download: https://www.joghr.org/article/21951-the-covid-19-global-pandemic-a-review-of-the-vietnamesegovernment-response/attachment/56256.pdf

\section{Appendix 2}

Download: https://www.joghr.org/article/21951-the-covid-19-global-pandemic-a-review-of-the-vietnamesegovernment-response/attachment/56494.pdf 